\title{
The Association of Serum Estradiol Level with the Susceptibility and Clinicopathological Features of Hepatocellular Carcinoma in Patients with Nonalcoholic Fatty Liver Disease
}

\author{
NEARMEEN M. RASHAD, M.D.*; SHERWEET M. AHMED, M.D.**; MAHA A. FATHY, M.D.*** and \\ SHADY E. SHAKER, M.D.* \\ The Departments of Internal Medicine*, Tropical Medicine** and Physiology***, Faculty of Medicine, Zagazig University, \\ Zagazig, Egypt
}

\begin{abstract}
Background: Non-alcoholic fatty liver disease (NAFLD) is one of the most common chronic liver diseases worldwide. The most common underlying causes of Hepatocellular carcinoma (HCC) are chronic liver diseases and cirrhosis.
\end{abstract}

Aim of Study: Our study aimed to investigate the serum estradiol levels in patients with nonalcoholics steatohepatitis (NASH) related HCC and to explore their correlations with clinicopathological features of HCC.

Patients and Methods: A Controlled Cross-Sectional Study included 200 patients with NAFLD (181 patients with NAFLD and 23 patients with NAFLD related HCC) and 50 controls. Serum estradiol was measured by enzyme-linked immunosorbent assay (ELISA).

Results: The serum level of estradiol was significantly lowered in patients with NAFLD $(32.24 \pm 7.3 \mathrm{pg} / \mathrm{ml})$ compared to controls $(42.9 \pm 3.9 \mathrm{pg} / \mathrm{ml})$. Moreover, our findings revealed lower concentrations of serum estradiol in the HCC group $(28.6 \pm 5.3 \mathrm{pg} / \mathrm{ml})$ compared to the NAFLD group $(33.45$ $\pm 4.3 \mathrm{pg} / \mathrm{ml}, p<0.001)$. We found significant negative correlations between serum estradiol levels and clinicopathological features of HCC (portal vein thrombosis, lymph node metastasis, number of tumor lesions, advanced clinical stage, tumor size, tumor site, distant metastasis) in patients with NAFLD complicated with HCC. linear regression test and we observed that serum triglycerides and $\alpha$-fetoprotein were significantly associated with serum estradiol among the HCC group.

Conclusion: Serum estradiol level was significantly lowered in the HCC subgroup compared to the NAFLD group and negatively correlated with clinicopathological features of HCC. Serum estradiol can be used as a promising predictor of HCC in female patients with NAFLD.

Key Words: Hepatocellular carcinoma - NAFLD - Estradiol - Clinicopathological features.

Correspondence to: Dr. Nearmeen M. Rashad,

E-Mail: nrashad 78@yahoo.com. n.rashad@zu.edu.eg.

\section{Introduction}

HEPATOCELLULAR carcinoma (HCC) is a complex and heterogeneous tumor with several genomic alterations and its incidence has been increasing worldwide. It is the sixth most common cancer and the second cause of cancer-related death [1].

Nonalcoholic fatty liver disease (NAFLD) is a spectrum of liver diseases ranging from simple steatosis to liver injury. The initial stage of an inflammatory phase in NAFLD is defined as nonalcoholic steatohepatitis (NASH) [2] . NASH is characterized by inflammation, hepatocellular damage, and fibrosis, which increase the risk of HCC with high rates of mortality.

The progression of NAFLD-related HCC is a complex and multifactorial process, including several risk factors such as genomic variability, obesity, or diabetes [3,4]. The development of HCC is considered the end result of most liver diseases, including viral hepatitis(C and B), NAFLD and alcoholic liver disease.

HCC may be modulated by both sex hormones during its initiation, progression, and metastasis [5-7]. Elevated levels of androgen are considered to promote tumorigenesis, while studies in the past decades showed that the roles of estrogen in HCC are diverse, even the opposite [8].

Estrogen is found to attenuate HCC progression by regulating cell proliferation, invasion, and apoptosis by inhibiting ER- $\alpha$-induced NF- $\kappa B$ signaling [9]. NF- $\kappa \mathrm{B}$ is highly associated with cancerrelated inflammation, and estrogen inhibits NF$\kappa \mathrm{B}$ signaling; therefore, a novel model that fully 
captures the complex behavior of human HCC generation is required to understand the molecular mechanism by which the origin of HCC is modulated [10]

The incidence of HCC is higher in males than females irrespective of the etiology. This suggests that the differential endocrine signaling might increase the tendency of HCC development in NAFLD-patients The treatment of liver cancer is a difficult task, especially among end-stage patients, whose lesions are usually thought to be unresectable Therefore, we aimed to investigate the serum estradiol levels in patients with NAFLD-related HCC and to explore their correlations with clinicopathological features of HCC.

\section{Patients and Methods}

A Controlled Cross-Sectional Study was conducted at Internal Medicine and Tropical Medicine Departments; Faculty of Medicine, Zagazig University, from September 2017 to September 2019. The Ethics Committee of Faculty of Medicine, Zagazig University approved this work. All participants assigned informed written consent prior to their inclusion. NAFLD was diagnosed upon ultrasonographic finding of bright liver according to the standard criteria accepted by the American Gastroenterology Association. A confirmatory liver biopsy was done. Among female patients with NAFLD; we found 181 female patients without HCC and 23 patients with HCC Also, we enrolled 50 age matched healthy female volunteers without liver disease. All participants underwent complete history taking and thorough clinical examination, patients with a history of viral hepatits, metabolic liver disease, heart disease, kidney disease, diabetes mellitus, or other cancers were excluded. None of the cases received neoadjuvant chemotherapy, radiotherapy, hormonal replacement therapy or immunotherapy.

All patients were subjected to abdominal ultrasonography using probe $3.5 \mathrm{MHZ}$ of TDI Philips machine. Liver biopsies were obtained using an automated gun device and under complete aseptic precautions. Pathological examination of liver biopsy was performed by an experienced pathologist who was blinded for patient data. A semiquantitatively evaluation of steatosis, lobular inflammation, ballooning, and liver fibrosis were done according to the NASH CRN scoring system [11].

HCC was diagnosed according to the American Association for the Study of Liver Diseases practice guidelines. Clinical staging of HCC was evaluated according to the Barcelona Clinic Liver Cancer staging classification [12] and Child-Pugh classification [13]. Clinicopathological features of HCC cases including tumor number, size, site, presence of metastasis, and portal vein thrombosis were obtained at the time of blood collection.

\section{Sampling of blood:}

The blood samples of all study's subjects were drawn after an overnight fast Sera were separated from the remaining sample part and stored at $-20{ }^{\circ} \mathrm{C}$ until analysis. Serum alanine aminotransferase (ALT), aspartate aminotransferase (AST), albumin, total bilirubin, and creatinine were estimated by routine enzymatic methods (spinreact). Serum alpha-fetoprotein (AFP) levels were measured using enzyme-linked immunosorbent assay (ELISA) kit (Biosource Europe S.A, Belgium). Viral markers including hepatitis B surface antigen (HB$\mathrm{sAg}$ ) and $\mathrm{HCV}$ antibodies (HCV-Ab), serum estradiol, (E2) were measured by ELISA (Abbott Laboratories, North Chicago, IL).

\section{Statistical analysis:}

The collected data were coded, tabulated, and statistically analyzed using IBM SPSS statistics (Statistical Package for Social Sciences) software version 22.0, IBM Corp., Chicago, USA, 2013. Descriptive statistics were done for quantitative data as minimum and maximum of the range as well as mean \pm SD (standard deviation) for quantitative parametric data, while it was done for qualitative data as the number and percentage. Odd ratio $(\mathrm{OR})$ and its $95 \%$ confidence interval (CI) were calculated. The relationships of serum estradiol levels with clinical and laboratory parameters among HCC patients were tested with the Pearson correlation. Linear regression analysis was done to detect the main independent variables associated with serum estradiol in the HCC group. Receiver operating characteristic (ROC) analysis was performed to assess the diagnostic power of serum estradiol. We considered $p$ to be significant at $<0.05$ with a $95 \%$ confidence interval (CI).

\section{Results}

Clinic-demographic characteristics of the study's participants:

As clarified in Table (1), no significant differences were observed in age, BMI, FPG, systolic and diastolic blood pressure between studied groups. However, there were significantly higher values of ALT, AST, total and direct bilirubin, international normalized ratio (INR), prothrombin time (PT), AFP, creatinine, and WBC count in 
patients with NAFLD compared to controls. On the other side, there were significantly lower values of albumin, hemoglobin and platelet count in patients with NASH compared to controls, $p<0.001$.

The clinic-demographic characteristics of patients with NAFLD were described in Table (2).

\section{Clinicopathological features of HCC patients:}

Among patients with $\mathrm{HCC}, 43.4 \%$ of patients had stage I/I I, tumors size more than $5 \mathrm{~cm}$ was observed in $47.9 \%$ of HCC patients. Lymph node metastasis was detected (39.2\%), distant metastasis $(43.4 \%)$, portal vein thrombosis $(47.9 \%)$, multiple tumor lesion (43.4), both lobe affection (30.4\%) among HCC patients, Table (3).

Table (1): Clinical and laboratory characteristics of the studied groups.

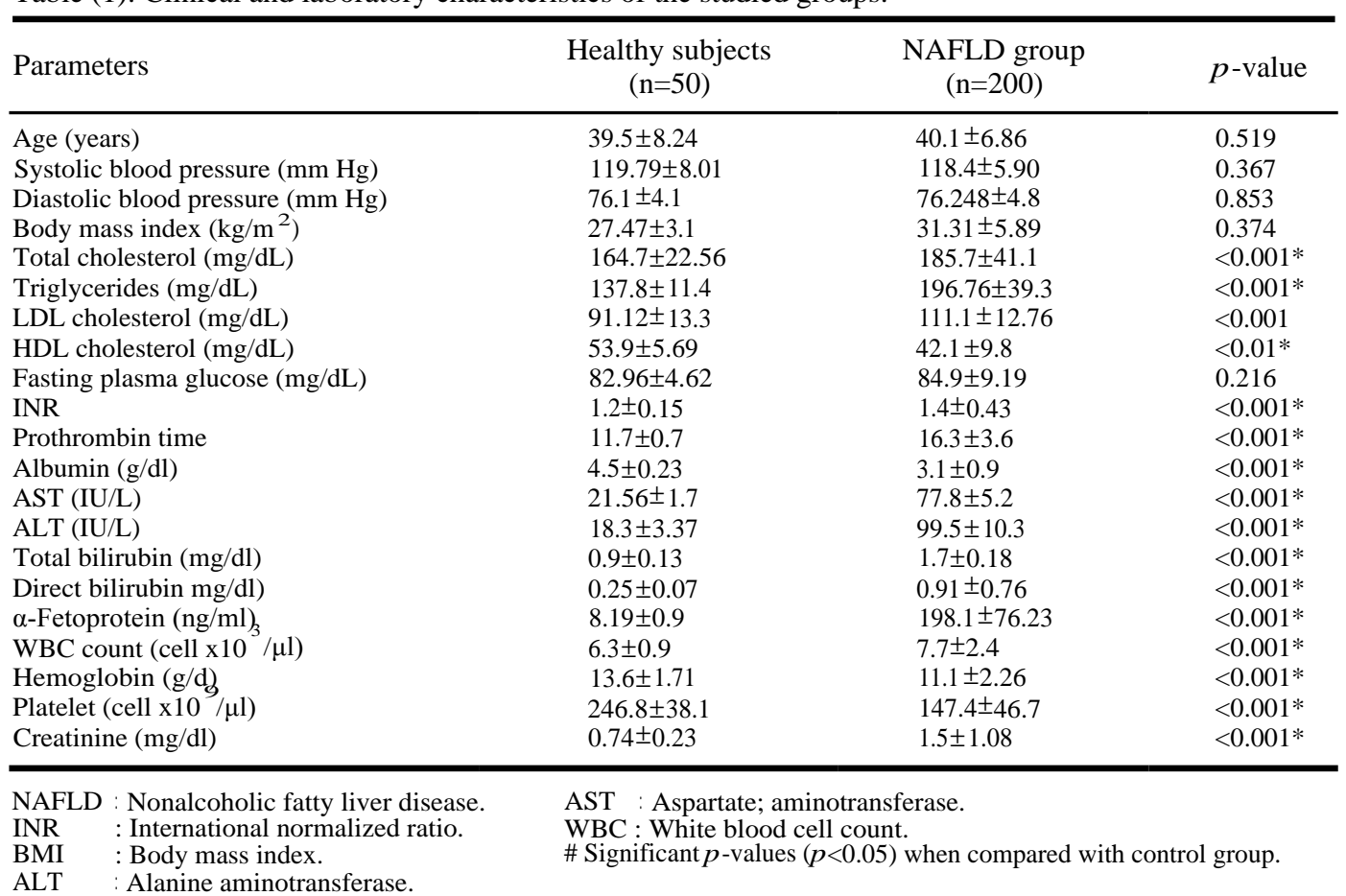

Table (2): Clinical and laboratory characteristics of the NAFLD groups.

\begin{tabular}{|c|c|c|c|}
\hline Parameters & $\begin{array}{l}\text { NAFLD } \\
(\mathrm{n}=181)\end{array}$ & $\begin{array}{c}\mathrm{HCC} \\
(n=23)\end{array}$ & $p$-value \\
\hline Age (years) & $39.5 \pm 6.24$ & $41.7 \pm 5.86$ & 0.402 \\
\hline Systolic blood pressure (mm Hg) & $118.79 \pm 6.01$ & $118.4 \pm 3.90$ & 0.953 \\
\hline Diastolic blood pressure (mm Hg) & $76.65 \pm 4.8$ & $75.48 \pm 4.9$ & 0.822 \\
\hline Body mass index $\left(\mathrm{kg} / \mathrm{m}^{2}\right)$ & $32.47 \pm 9.05$ & $26.31 \pm 5.89$ & 0.384 \\
\hline Total cholesterol (mg/dL) & $109.7 \pm 22.56$ & $101.7 \pm 17.1$ & 0.275 \\
\hline Triglycerides (mg/dL) & $200.8 \pm 44.4$ & $184.76 \pm 23.39$ & $<0.001 *$ \\
\hline LDL cholesterol (mg/dL) & $128.12 \pm 40.3$ & $145.1 \pm 46.76$ & 0.049 \\
\hline HDL cholesterol (mg/dL) & $43.9 \pm 8.69$ & $41.1 \pm 6.8$ & 0.238 \\
\hline Fasting plasma glucose $(\mathrm{mg} / \mathrm{dL})$ & $82.96 \pm 4.62$ & $140.9 \pm 30.19$ & $<0.001 *$ \\
\hline INR & $1.1 \pm 0.05$ & $1.4 \pm 0.33$ & 0.194 \\
\hline Prothrombin time & $12.7 \pm 0.7$ & $18.3 \pm 3.6$ & $<0.001 *$ \\
\hline Albumin $(\mathrm{g} / \mathrm{dl})$ & $3.2 \pm 0.23$ & $2.5 \pm 0.9$ & $<0.001 *$ \\
\hline AST (IU/L) & $72.56 \pm 1.7$ & $91.8 \pm 5.2$ & $<0.001 *$ \\
\hline ALT (IU/L) & $55.3 \pm 3.37$ & $111.5 \pm 10.3$ & $<0.001 *$ \\
\hline Total bilirubin (mg/dl) & $1.9 \pm 0.13$ & $3.6 \pm 1.18$ & $<0.001 *$ \\
\hline Direct bilirubin $\mathrm{mg} / \mathrm{dl}$ ) & $0.55 \pm 0.07$ & $2.31 \pm 0.76$ & $<0.001 *$ \\
\hline$\alpha$-Fetoprotein $(\mathrm{ng} / \mathrm{ml})_{3}(\mathrm{ng} / \mathrm{ml})$ & $6.19 \pm 0.9$ & $12.1 \pm 4.4$ & $<0.001 *$ \\
\hline WBC count $($ cell $\times 10 / \mu \mathrm{l})$ & $6.3 \pm 0.9$ & $7.7 \pm 2.4$ & $<0.001 *$ \\
\hline Hemoglobin $(\mathrm{g} / \mathrm{d})$ & $11.6 \pm 0.71$ & $10.9 \pm 2.56$ & 0.216 \\
\hline Platelet $($ cell $\times 10 \% / \mu 1)$ & $236.8 \pm 38.1$ & $131.4 \pm 46.7$ & $<0.001 *$ \\
\hline Creatinine $(\mathrm{mg} / \mathrm{dl})$ & $1.01 \pm 0.23$ & $1.8 \pm 1.08$ & $<0.001 *$ \\
\hline $\begin{array}{ll}\text { NAFLD } & \text { Nonalcoholic fatty liver disease. } \\
\text { INR } & \text { : International normalized ratio. } \\
\text { BMI } & \text { : Body mass index. } \\
\text { ALT } & \text { : Alanine aminotransferase. }\end{array}$ & $\begin{array}{l}\text { AST : Aspart } \\
\text { WBC : White } \\
\text { \# Significant } p\end{array}$ & $\begin{array}{l}\text { isferase. } \\
\text { int. } \\
\text { 5) when compar }\end{array}$ & D group. \\
\hline
\end{tabular}


Table (3): Clinicopathological features of HCC patients.

\begin{tabular}{|c|c|c|}
\hline & $\begin{array}{l}\text { HCC patients } \\
(n=23) n(\%)\end{array}$ & $p$ value \\
\hline \multicolumn{3}{|l|}{ Clinical stage: } \\
\hline Stage I/II & $10(43.4)$ & 0.532 \\
\hline Stage III/IV & $13(56.6)$ & \\
\hline \multicolumn{3}{|l|}{ Tumor size: } \\
\hline$<5 \mathrm{~cm}$ & $11(47.9)$ & 0.835 \\
\hline$>5 \mathrm{~cm}$ & $12(52.1)$ & \\
\hline \multicolumn{3}{|c|}{ Lymph node metastasis: } \\
\hline Absent & $14(60.8)$ & 0.297 \\
\hline Present & $9(39.2)$ & \\
\hline \multicolumn{3}{|c|}{ Distant metastasis: } \\
\hline Absent & $13(56.6)$ & 0.532 \\
\hline Present & $10(43.4)$ & \\
\hline \multicolumn{3}{|c|}{ Child -pugh grade: } \\
\hline A & $7(30.4)$ & 0.957 \\
\hline B & $9(39.2)$ & \\
\hline $\mathrm{C}$ & $7(30.4)$ & \\
\hline \multicolumn{3}{|c|}{ Portal vein thrombosis: } \\
\hline Negative & $12(52.1)$ & 0.835 \\
\hline Positive & 11(47.9) & \\
\hline \multicolumn{3}{|c|}{ Number of tumour lesions: } \\
\hline Single & $13(56.6)$ & 0.532 \\
\hline Multipole & $10(43.4)$ & \\
\hline \multicolumn{3}{|l|}{ Site of lesions: } \\
\hline Right lobe & $11(47.9)$ & 0.296 \\
\hline Left lobe & $5(21.7)$ & \\
\hline Both & $7(30.4)$ & \\
\hline
\end{tabular}

Circulating estradiol levels in serum among studied groups:

The serum level of estradiol was significantly lowered in patients with NAFLD $(32.24 \pm 7.3 \mathrm{pg} / \mathrm{ml})$ in comparison to controls $(42.9 \pm 3.9 \mathrm{pg} / \mathrm{ml})$, (Fig. $1 \mathrm{a}, p<0.001)$. In a similar context, our findings revealed lower concentrations of serum estradiol in HCC group $(28.6 \pm 5.3 \mathrm{pg} / \mathrm{ml})$ compared to NAFLD group (33.45 $\pm 4.3 \mathrm{pg} / \mathrm{ml}$ ) (Fig. $1 \mathrm{~b}, p^{<}$ 0.001 ).
Correlation between serum estradiol levels $(\mathrm{pg} / \mathrm{ml})$ levels with laboratory characteristic of HCC:

There were significant negative correlations between serum estradiol levels and serum triglycerides as well as $\alpha$-fetoprotein $(p<0.001$, Table 4$)$.

Linear regression analyses to explore the main independent variables associated with serum estradiol levels (dependent variable) among case group:

Linear regression test revealed that serum triglycerides, as well as $\alpha$-fetoprotein, were significantly associated with serum estradiol among case group $(p<0.001$, Table 5).

The diagnostic power of serum estradiol level among study's groups:

ROC analysis was done to detect an optimum cut-off value of serum estradiol level for diagnosis of NAFLD cases among healthy individual it was $32.8(\mathrm{ng} / \mathrm{ml})$. Fig. (2a) revealed that $\mathrm{AUC}=0.826$, (95\%): 0.751-0.901), $p<0.001$ with sensitivity $(96 \%)$ and specificity (95.6\%). Moreover, ROC analysis was done for discriminating $\mathrm{HCC}$ from those patients with NAFLD with an AUC $=0.927$, (95\%): 0.884-0.971) with sensitivity (92\%) and specificity $(72 \%)$ at a cutoff of $42.8(\mathrm{ng} / \mathrm{ml})$.

Table (4): Pearson correlations of serum E2 with laboratory and clinicopathological features of HCC.

\begin{tabular}{|c|c|c|}
\hline \multirow{2}{*}{ Parameters } & \multicolumn{2}{|c|}{ E2 } \\
\hline & $r$ & $p$ \\
\hline Triglycerides & -0.981 & $<0.001 *$ \\
\hline$\alpha$-Fetoprotein & -0.875 & $<0.001 *$ \\
\hline Albumin (g/dl) & 0.043 & 0.704 \\
\hline AST (IU/L) & 0.037 & 0.74 \\
\hline ALT (IU/L) & 0.003 & 0.98 \\
\hline Total bilirubin (mg/dl) & 0.066 & 0.56 \\
\hline Direct bilirubin (mg/d 1$)$ & 0.136 & 0.23 \\
\hline WBC count (cell $\left.\times 10^{3} / \mathbf{I}\right) \mathbf{c}$ & 0.325 & 0.003 \\
\hline Hemoglobin $\left(\mathrm{g} / \mathrm{dl}_{3}\right)$ & 0.113 & 0.32 \\
\hline Platelet (cell x10 / / 1 e & 0.085 & 0.46 \\
\hline Creatinine $(\mathrm{mg} / \mathrm{dl})$ & 0.201 & 0.07 \\
\hline
\end{tabular}

Table (5): Linear regression analysis for the main independent variables associated with serum estradiol level (dependent variable) among case group.

\begin{tabular}{|c|c|c|c|c|c|c|c|}
\hline \multirow{2}{*}{ Model } & \multicolumn{2}{|c|}{ Unstandardized coefficients } & \multirow{2}{*}{$\frac{\text { Standardized coefficients }}{\text { Beta }}$} & \multirow{2}{*}{$t$} & \multirow{2}{*}{$p$-value } & \multicolumn{2}{|c|}{ 95\% C.I. } \\
\hline & $\beta$ & Std. error & & & & Lower bound & Upper bound \\
\hline (Constant) & 37.990 & 3.643 & & 10.427 & 0.000 & 30.755 & 45.225 \\
\hline Direct bilirubin & 0.021 & 0.280 & 0.008 & 0.077 & 0.939 & -0.534 & 0.577 \\
\hline ALT & -0.003 & 0.007 & -0.043 & -0.448 & 0.655 & -0.016 & 0.010 \\
\hline TG & -0.044 & 0.012 & -0.322 & -3.537 & 0.001 & -0.068 & -0.019 \\
\hline BMI & 0.021 & 0.016 & 0.115 & 1.282 & 0.203 & -0.011 & 0.053 \\
\hline Platelet & 0.022 & 0.014 & 0.169 & 1.569 & 0.120 & -0.006 & 0.051 \\
\hline$\alpha$-Fetoprotein & -0.009 & 0.003 & -0.298 & -2.770 & 0.007 & -0.015 & -0.003 \\
\hline
\end{tabular}



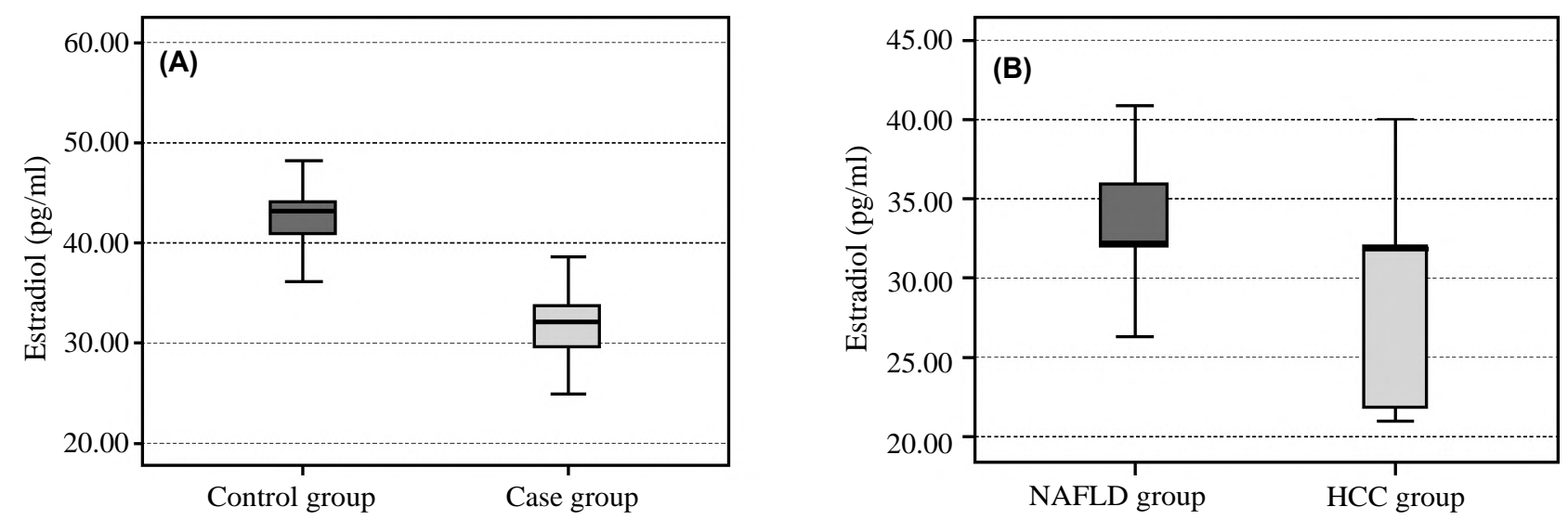

Fig. (1): (A): Comparison of serum estradiol level in the studied groups. (B): Comparison of serum estradiol level in NAFLD groups.
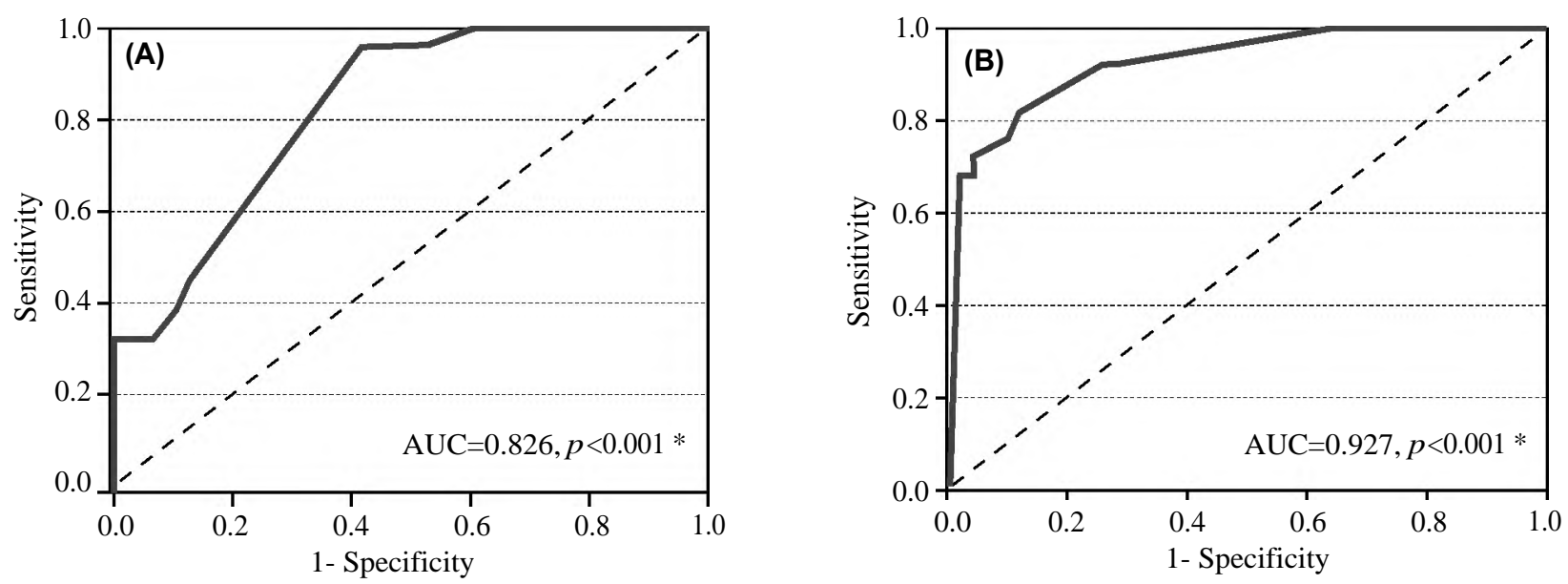

Fig. (2): (A): Receiver operating characteristic curve for serum estradiol level in discriminating between patients with NAFLD and controls. (B): Receiver operating characteristic (ROC) curve for serum estradiol in differentiating between patients with HCC and patient with NAFLD.

\section{Discussion}

Accumulating studies have reported that HCC is the third-leading cause of cancer deaths worldwide, to date, a number of epidemiological studies have identified several risk factors for HCC [15] The development of HCC is considered the end result of most liver diseases, including viral hepatitis, cirrhosis and alcoholic liver disease. The incidence of NASH and HCC is higher in males irrespective of the etiology. This suggests that the differential endocrine signaling might increase the tendency of HCC development in NASH patients. Both estrogen and androgen are steroid hormones that mediate their action by binding to nuclear receptors and acting as transcription factors to regulate the expression of multiple genes. It was suggested that androgen and androgen receptors (ARs) might promote HCC progression and/or that estrogen and estrogen receptors might suppress HCC development [16]. ARs can be activated by different signaling pathways such as MAPK and PI3K, which are well-known in the development of HCC in NAFLD [17].

The treatment of liver cancer is a difficult task, especially among end-stage patients, whose lesions are usually thought to be unresectable.in the current study, we attempted to investigate the molecular mechanism underlying such disparity, in addition, to assess the association between serum estradiol in female patients with NAFLD-related HCC and clinicopathological features of HCC.

The main finding of the present study is that among 200 studied female patients with biopsy proven NAFLD, 23 patient had HCC (11.5\%).

The risk factors of develop ing $\mathrm{HCC}$ in NASH may be attributed to the following-over weight, increased level of insulin and excess of hepatic iron load, resulting in advanced fibrosis and cirrhosis. In addition, age and sex are also considered 
as risk factors for NASH-HCC [18] The evidence mentioned above demonstrated that actual prevalence of NASH-HCC is unknown as the underlying pathology of NAFLD/NASH is not well defined [19]. Said and Ghufran observed that the annual incidence of NAFLD-associated HCC is $2.6 \%$, $2.4 \%$ at seven years and $12.8 \%$ over three years [20].

The current study found that the serum estradiol level was significantly lowered in patients with NAFLD in comparison to controls. In addition, our findings revealed lower concentrations of serum estradiol in the HCC group compared to the NAFLD group. HCC is inflammation-related cancer and estrogen may play its protective role through its anti-inflammation effects.

Similar results detected by $\mathrm{Xu}$ et al., they found that estrogen has a protective role in HCC and they explained this finding as estrogen regulates cell proliferation, invasion and apoptosis by inhibiting ER- $\alpha$-induced NF- $\downarrow \chi B$ signaling [21]

In agreement with our results, Francavilla et al observed that the effect of estrogen in HCC has turned from an oncogenic to protective role based on recent discoveries that NF- $\chi \mathrm{B}$ is highly associated with cancer-related inflammation, and estrogen inhibits NF- $\downarrow \chi \mathrm{B}$ signaling [22] .

The results presented here are important; as this study investigated the possible association of serum estradiol with clinicopathological features of HCC including [portal vein thrombosis, lymph node metastasis, number of tumor lesions, advanced clinical stage, tumor size, tumor site, distant metastasis] and we found significantly negative correlations between serum estradiol levels and these parameters in patients with NAFLD complicated with HCC.

In line with our results, Kalra et al., found that HCC may be modulated by both sex hormones during its initiation, progression, and metastasis [23].

Mounting evidence indicates that postmenopausal females lacking circulating estrogen show accelerated the progression of $\mathrm{HCV}$-infection to fibrosis and HCC development [24,25]. In addition, physiological estrogen levels seen in premenopausal females, have been associated with less severity and slow progression through all stages of $\mathrm{HCV}$ infection [26,27].

In line with the current knowledge, experimental studies demonstrating that administration of 170 - estradiol inhibits HCC development in vitro and in vivo $[28,29]$.

For further evaluation, we analyzed our results using a linear regression test and we observed that serum triglycerides and $\alpha$-Fetoprotein were significantly associated with serum estradiol among the HCC group. Interestingly, ROC analyses revealed that the power of serum estradiol in discriminating $\mathrm{HCC}$ cases from NASH patients was more potent than the diagnostic power of estradiol in differentiating NASH from controls.

In conclusion: Serum estradiol level was lower in patients with HCC compared to healthy controls, Interestingly, serum estradiol levels were significantly correlated with clinicopathological features of HCC (portal vein thrombosis, lymph node metastasis, number of tumor lesions, advanced clinical stage, tumor size, tumor site, distant metastasis).

\section{Recommendation:}

serum estradiol could be considered prognostic markers of HCC. Further large studied about the effective therapy using sex hormones. Hormonerelated therapy in HCC is needed.

\section{Competing interests:}

The authors declare that they have no competing interests to disclose.

\section{Acknowledgment:}

The authors would like to thank all the patients and healthy controls accepted to participate in this study. Also, The authors would like to thank all collageues in Clinical Pathology and Radiology Departments, Zagazig University for their help during this study.

\section{References}

1- European Association for the Study of the Liver and European Organisation For Research And Treatment Of Cancer. EASL-EORTC clinical practice guidelines: Management of hepatocellular carcinoma. J. Hepatol., 56: 908-43, 2012

2- BELLENTANI S.: "The epidemiology of the non-alcoholic fatty liver disease", Liver International, Vol. 37, pp. 8184, 2017.

3- ASCHA M.S., HANOUNEH I.A., LOPEZ R.,TAMIAMI T.A.R., FELDSTEIN A.F. and ZEIN N.N.: "The incidence and risk factors of hepatocellular carcinoma in patients with nonalcoholic steatohepatitis", Hepatol., 51 (6): 19721978, 2010.

4- SAID A. and GHUFRAN A.: "Epidemic of non-alcoholic fatty liver disease and hepatocellular carcinoma," World Journal of Clinical Oncology, Vol. 8, No. 6, pp. 429-36, 2017. 
5- KALRA M., MAYES J., ASSEFA S., KAUL A.K. and KAUL R.: Role of sex steroid receptors in pathobiology of hepatocellular carcinoma. World. J. Gastroenterol., 14: 5945-5961. doi: 10.3748/wjg.14.5945, 2008.

6- GIANNITRAPANI L., SORESI M., LA SPADA E., CERVELLO M., D'ALESSANDRO N. and MONTALTO G.: Sex hormones and risk of liver tumor. Ann. N.Y. Acad. Sci., 1089: 228-236. doi: 10.1196/annals. 1386. 044, 2006.

7- DE MARIA N., MANNO M. and VILLA E.: Sex hormones and liver cancer. Mol. Cell. Endocrinol., 193: 59-63. doi: 10.1016/S0303-7207 (02) 00096-5, 2002.

8- PIGNATA S., DANIELE B., GALLO C., DE VIVO R., MONFARDINI S. and PERRONE F.: Endocrine treatment of hepatocellular carcinoma. Any evidence of benefit? Eur. J. Cancer, 34: 25-32. doi: 10.1016/S0959-8049(97) 00317-1, 1998.

9- XU H., WEI Y., ZHANG Y., XU Y., LI F., LIU J., ZHANG W., HAN X., TAN R. and SHEN P.: Oestrogen attenuates tumour progression in hepatocellular carcinoma. J. Pathol., 228: 216-229. doi: 10.1002/path.4009, 2012.

10- FRANCAVILLA A., POLIMENO L., BARONE M., AZZARONE A. and STARZL T.E.: Hepatic regeneration and growth factors. J. Surg. Oncol., Suppl. 3: 1-7, 1993.

11- KLEINER D.E., BRUNT E.M., VAN NATT A M., BEHLING C., CONTOS M.J., CUMMINGS O.W., FERRELL L.D., LIU Y.C., TORBENSON M.S., UNALP ARIDA A. and YEH M.: Design and validation of a histological scoring system for nonalcoholic fatty liver disease. Hepatology, 41 (6): 1313-1321, 2005.

12- LIOVET J.M., BR U.C. and BRUIX J.: Prognosis of hepatocellular carcinoma: The BCLC staging classification. Semin Liver Dis., 19: 329-38, 1999.

13- PUGH R.N., MURRAY-LYON I.M., DAWSON J.L., et al.: Transection of the oesophagus for bleeding oesophageal varices. Br. J. Surg., 60: 646-9, 1973.

14- AL KINDI M.K., AL ESSRY F.S., AL ESSRY F.S. and MULA-ABED W.A.: Validity of serum testosterone, free androgen index, and calculated free testosterone in women with suspected hyperandrogenism. Oman. Med. J., 27: 471-474, 2012.

15- JEMAL A., BRAY F., CENTER M.M., FERLAY J., WARD E. and FORMAN D.: Global cancer statistics. CA. Cancer. J. Clin., 61: 69-90. doi: 10.3322/caac. 20107 , 2011.

16- NAGASUE N., YU L., YUKAYA H., KOHNO H. and NAKAMURA T.: "Androgen and oestrogen receptors in hepatocellular carcinoma and surrounding liver parenchyma: Impact on intrahepatic recurrence after hepatic resection," British Journal of Surgery, Vol. 82, No. 4, pp. 542547, 1995.
17- KANDA T., JIANG X. and YOKOSUKA O.: "Androgen receptor signaling in hepatocellular carcinoma and pancreatic cancers," World Journal of Gastroenterology, Vol. 20, No. 28, pp. 9229-9236, 2014.

18- KIKUCHI L., OLIVEIRA C.P. and CARRILHO F.J. Nonalcoholic fatty liver disease and hepatocellular carcinoma. Biomed Res. Int., 2014: 106247, 2014.

19- BUGIANESI E., LEONE N., VANNI E., MARCHESINI G., BRUNELLO F., CARUCCI P., et al.: Expanding the natural history of nonalcoholic steatohepatitis: From cryptogenic cirrhosis to hepatocellular carcinoma. Gastroenterology, 123: 134-40, 2002.

20- SAID A. and GHUFRAN A.: Epidemic of non-alcoholic fatty liver disease and hepatocellular carcinoma. World J. Clin. Oncol., 8: 429-36, 2017.

21- XU H., WEI Y., ZHANG Y., XU Y., LI F., LIU J., ZHANG W., HAN X., TAN R. and SHEN P.: Oestrogen attenuates tumour progression in hepatocellular carcinoma. J. Pathol., 228: 216-229. doi: 10.1002/path.4009, 2012.

22- FRANCAVILLA A., POLIMENO L., BARONE M., AZZARONE A. and STARZL T.E.: Hepatic regeneration and growth factors. J. Surg. Oncol., Suppl. 3: 1-7, 1993.

23- KALRA M., MAYES J., ASSEFA S., KAUL A.K. and KAUL R.: Role of sex steroid receptors in pathobiology of hepatocellular carcinoma. World J. Gastroenterol., 14: 5945-5961. doi: 10.3748/wjg. 14.5945, 2008.

24. DI MARTINO V., LEBRAY P., MYERS R.P., PANNIER E., PARADIS V., CHARLOTTE F., MOUSSALLI J., THABUT D., BUFFET C. and POYNARD T.: Progression of liver fibrosis in women infected with hepatitis C: Longterm benefit of estrogen exposure. Hepatology, 40: 14261433, 2004.

25- YU J.W., SUN L.J., ZHAO Y.H., KANG P. and YAN B.Z.: Impact of sex on virologic response rates in genotype 1 chronic hepatitis $\mathrm{C}$ patients with peginterferon alpha-2a and ribavirin treatment. Int. J. Infect. Dis., 15: e740-e746, 2011.

26- SHIMIZU I.: Impact of oestrogens on the progression of liver disease. Liver. Int., 23: 63-69, 2003.

27- IWAMURA K.: Clinical significance of estrogens in chronic aggressive hepatitis. Acta. Hepatogastroenterol., (Stuttg) 26: 267-278, 1979.

28- NAKATANI T., ROY G., FUJIMOTO N., ASAHARA T. and ITO A.: Sex hormone dependency of diethylnitrosamine-induced liver tumors in mice and chemoprevention by leuprorelin. Jpn. J. Cancer. Res., 92: 249-256, 2001.

29- NAUGLER W.E., SAKURAI T., KIM S., MAEDA S., KIM K., ELSHARKAWY A.M. and KARIN M.: Gender disparity in liver cancer due to sex differences in MyD88dependent IL-6 production. Science, 317: 121-124, 2007. 


\section{ارتباط مستوى استراديول المصل مع الحساسية والمرضية

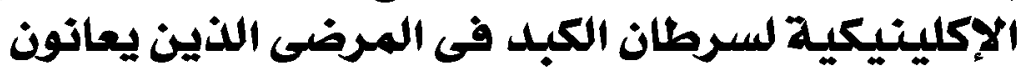 \\ من مرضالكبد الدهنى غير الكحولى الهيلى الكين}

يعد مرض الكبد الدهنى غير الكحولى من أكثر أمراض الكبد المزمنة شيوعاً فى جميع أنحاء العالم. والأسباب الكامنة الاكثر شيوعاً لسرطان

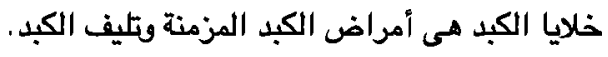

تهدف دراستنا إلى التحقيق فى مستويات استراديول فى المرضى الذين يعانون من التهاب الكبد الدهنى غير الكحولى واستكثاف علاقاتهم مع سرطان الكبد.

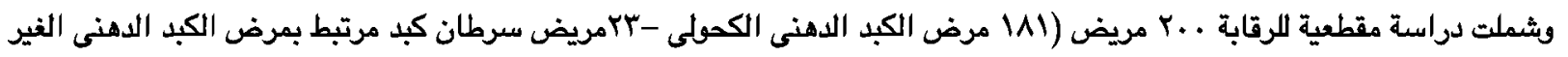

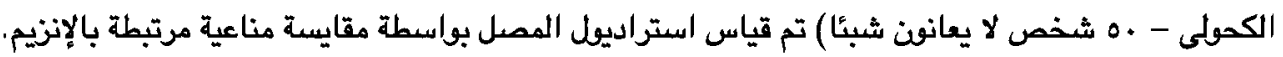

النتأج: ان مستوى استراديول المصل منخفضوٌ بشكل كبير فى المجموعة سرطانات الكبد مقارنة مع مجموعة مرضى الكبد الدهنى غير الكحولى. يمكن استخدامها كمؤشر واعد من فى المرضى الأناث مع مرضى سرطان الكبد فى مرض الكبد الدهنى غير الكحولى. 